perturbation by nearly cylindrical ducts, by slender bodies of arbitrary cross-section bearing wings of small aspect ratio, and by thin wings of intermediate aspect ratio. $\mathrm{He}$ is particularly interested in the teaching of mathematics to engineers in such a way that they may be enabled to make full use of it in their work.

\section{Bird Exploration Fund}

THE recent institution of the Bird Exploration Fund is a joint effort by officials of the British Museum (Natural History) and private individuals to fill a need brought about by the economic conditions of present times. The days of private expeditions financed by public-spirited naturalists, which contributed so largely to the study collections of the British Museum, are now past. 'The importance of scientifically conducted field investigations in conjunction with collecting is widely recognized, and if the knowledge of birds by the collection of specimens is to be extended it is essential that expeditions should be continued. The aim of the newly formed Fund is to make this possible. Vested in trustees and with the official approval of the British Museum, the general purposes of the Fund are stated to be "promoting, organizing and financing in whole, or in part, ormithological expeditions to, and bird explorations in, those parts of the world where bird life is least known". Specimens are to become the property of the British Museum; but collectors who take part in the expeditions will be given every reasonable facility for work and study in connexion with such specimens. It is perhaps not generally realized that public institutions are not readily endowed with private money. The formation of a permanent Fund gives those who wish to forward the science of ornithology an opportunity, by means of their collective support, to make possible these very important expeditions and thereby enrich the national Museum. The headquarters of the Fund are at the Bird Room, British Museum (Natural History), Cromwell Road, London, S.W.7, and all donations and inquiries should be sent to the SecretaryTreasurer.

\section{International Union for the Study of the Behaviour of Social Insects}

DurING the Ninth International Congress of Entomology, the termitologists and myrmecologists present decided to set up a permanent international union for the study of the behaviour of social insects. It is intended to approach workers on the social behaviour of insects all over the world and to organize the interchange of ideas and of research programmes from the earliest pre-publication stages, and also to build up a library of reprints for reference purposes. To this end, termitologists and myrmecologists are requested to send not only a complete bibliography of their papers to date, and details of their present projects, but also two reprints of each future paper and of as many past papers as possible. An international address list will also be assembled. It is hoped that it will soon be possible to publish a journal, which at first may be limited to brief notes, but which should eventually cover the field as adequately as possible. At Amsterdam a provisional committee was formed; but a constitutional committee will in due course be elected by the members of the new union. Further information can be obtained from D. Wragge Morley, Organizing Secretary, International Union for the Study of Social
Insects, $14 b$ Downshire Hill, Hampstead, London, N.W.3.

\section{Medical Research in East Africa}

INTERESTING information about the health risks of East Africa is contained in two reports issued by the East Africa High Commission. The annual report for 1950 of the Virus Research Institute (pp. 32. Nairobi : Government Printer, 1951) describes the history of the Institute, its buildings and staff and the work carried out in 1950. The Institute was formerly known as the Yellow Fever Research Institute, having been founded in 1936, and was taken over by the East Africa High Commission in 1950. One section of the report deals with yellow fever and its epidemiology and immunology. A number of sections discuss other viruses, poliomyelitis and rickettsioses, and there is a section on general entomology which includes work on ticks, mosquitoes, ectoparasites of trapped mammals, the biting habits of Tabanidæ and studies of the eradication of Simulium damnosum. The list of papers published or in the press is evidence of the activity of the staff. The annual report for 1950 of the East Africa Medical Survey (pp. 61; Nairobi : East Africa High Commission, 1951) shows that, in spite of a serious shortage of staff, both laboratory investigations and field surveys have been undertaken in the Mwanza area and on Ukara Island. The results of these are given., A feature of the report is the fact that food is rarely sufficient in quantity and lacks quality, women especially suffering because of taboos of important sources of protein. A survey of insect vectors of disease is to be carried out, and an entomologist records his brief survey of the distribution ${ }^{-}$of mosquitoes on Ukara Island. The report also discusses statistics so far available of the maternity histories, reproductive-rate and infant. mortality-rate.

\section{Atomic Heating System at Harwell}

A BUILDING containing eighty offices at the Ministry of Supply Atomic Research Establishment, Harwell, will now draw its heat direct from BEPO, the large experimental atom pile. 'This is the first atomic central-heating plant in the world. Eventually two, and perhaps three, more buildings will also have 'atomic radiators' and the Ministry's coal consumption will be cut by at least a thousand tons a year. After counting all incidental expenses, the saving in cash is estimated at $£ 2,650$ a year. Costs of the installation amount to $£ 15,000$.

The constant hot water which will flow through the pipes is obtained by placing a heat exchanger in the outlet air duct of the pile's air-cooling system. Here there is a by-pass fitted with a damper which ean be adjusted to vary the proportion of the air-flow passing through the heat exchanger. Hot water from the exchanger is then circulated in a closed circuit by a small pump to a secondary water-to-water heat exchanger. This supplies hot water for space heating and domestic hot water supplies. At present the air temperature at the primary heat exchanger is $135^{\circ} \mathrm{F}$., and the water itself is heated to $130^{\circ}$. In 1952 , when modifications to the pile have been completed, these temperatures will be substantially increased. There is no danger from radioactivity and the water can safely be used for washing. The heat output designed for the first building is one million B.Th.U. per hour, equal to about two hundred electric fires; but for the final installation the maximum output will be 